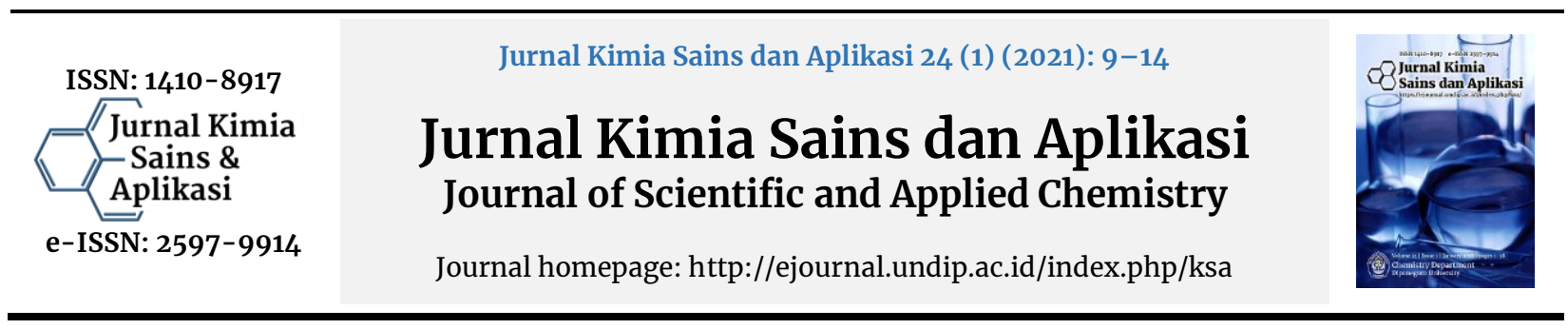

\title{
Aluminum Pillared Clay (Al-PILC) for Adsorption of Dyes in Red Fruit Oil
}

\author{
Sholihah Novitasari ${ }^{\mathrm{a}}$, Sriatun Sriatun ${ }^{\mathrm{a},}$, Taslimah ${ }^{\mathrm{a}}$ \\ a Department of Chemistry, Faculty of Science and Mathematics, Diponegoro University, Semarang, Indonesia \\ *Corresponding author: sriatun@live.undip.ac.id \\ https://doi.org/10.14710/jksa.24.1.9-14
}

\section{Article Info}

Article history:

Received: $11^{\text {th }}$ September 2020 Revised: $7^{\text {th }}$ February 2021

Accepted: $8^{\text {th }}$ February 2021

Online: $28^{\text {th }}$ February 2021

Keywords:

Al pillared clay; clay fraction; adsorption; carotene; red fruit oil

\begin{abstract}
Red fruit oil contains carotene, which is dark orange, so it is not very popular. Therefore, it is necessary to reduce the intensity of the color. Yesterday, in this study, the synthesis and characterization of Al-pillared clay (Al-PILC) from light and heavy clay fractions were carried out. The absorption capacity of red fruit carotene dyes was studied. The research stages included preparation, fractionation, activation, pillarization of clay with aluminum, characterization, and adsorption test for carotene dyes on red fruit. Characterization was carried out using X-ray Diffractometer (XRD) and Gas Sorption Analyzer (GSA). The results showed that basal spacing of natural clay, Al pillared heavy fraction-clay, Al pillared light fraction-clay, activated light fraction were $15.08 \AA, 15.27 \AA, 16.84$ $\AA$, and 16 , respectively. $22 \AA$. The GSA results showed that the surface area and pore volume of the Al pillared light fraction-clay of 0.3 was higher than the heavy fraction. The average pore size of Al pillared light fraction-clay and the heavy fraction was found in the mesoporous range of 30-100 $\AA$, and the adsorption isotherm is type IV. Al-pillared light fraction-clay had higher adsorption ability than a heavy fraction and light fraction before pillaring. When the pillaring agent's concentration was $0.3 \mathrm{M}$, Al pillared heavy fraction-has absorption capacity is $58.66 \%$, while Al pillared light fraction-clay is $90.4 \%$.
\end{abstract}

\section{Introduction}

The red fruit (Pandanus conoideus Lam.) is an endemic plant that grows on Papua island. Red fruit contains high levels of carotenoids [1], $\beta$-cryptoxanthin, $\alpha$-tocopherol, and unsaturated fatty acids [2, 3]. Carotenoids are a group of pigments that are yellow, orange, or orange-red. It is found in plants, skins, shells/exoskeletons of aquatic animals, and other marine products such as mollusks (calm, oyster, scallops), crustaceans (lobsters, crabs, prawns), and fish (salmon, trout, sea bream, red snapper, and tuna). Carotenoids are also found in many bacteria, fungi, algae, and green plants [4].

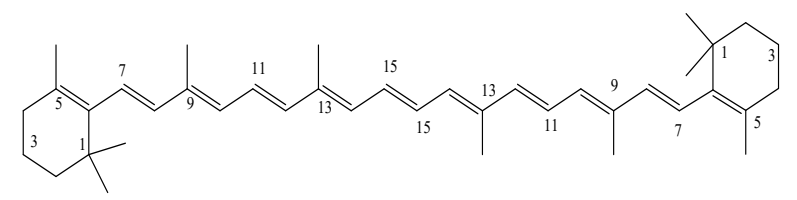

Figure 1. Carotene structure [5]
Red fruit oil has the potential to be used as food oil (cooking oil), but the intensity of the intense color gives a poor performance so that the selling value is low. The presence of conjugated double bonds in the carotene structure causes carotene to be easily isomerized and oxidized. Isomerization can occur due to heat application. The carotene structure, which is generally transgeometric, changes to cis so that provitamin A's activity in the compound decreases [6]. According to Sarungallo et al. [7], the duration of storage can reduce carotene levels. So, for red fruit oil to have a better and safer performance, it is necessary to blanch red fruit oil by reducing carotene levels.

Irvan et al. [8] have carried out adsorption of $\beta$ carotene using activated carbon adsorbent by varying the adsorbent/CPO (w/w) of $1 / 3,1 / 4,1 / 5$ and $1 / 6$ and the adsorption temperature of $40^{\circ} \mathrm{C}, 50^{\circ} \mathrm{C}$, and $60^{\circ} \mathrm{C}$. The results showed that the greater the amount of $\mathrm{CPO}$, the lower the adsorption percentage, while the higher the 
adsorption temperature, the adsorption increased. The maximum adsorption percentage of $95.108 \%$ was obtained at an adsorbent/CPO ratio of $1 / 3$ and $a$ temperature of $60^{\circ} \mathrm{C}$.

On the other hand, clay is an abundant natural mineral. It is cheap and can be used as an adsorbent [9]. Clays have been used for $\beta$-carotene reduction in palm oil [10] and soybean oil [11]. However, the adsorption capacity of clay is limited. This weakness can be overcome by activation and modification of the clay, such as through clay pillarization. Clay pillarization can increase the thermal stability, porosity, specific surface area, and acidity of the clay surface [12]. Pillared clays have several advantages, including a larger surface area and a larger total pore volume. The superior properties of pillared clay make it potential for use as an adsorbent even as a selective adsorbent [13].

Activated and pillared clays are proven to have better adsorption abilities. Nurhayati [14] reported that natural clay activated using $\mathrm{HCl}$ increased the surface area from $298 \mathrm{~m}^{2} / \mathrm{g}$ to $306 \mathrm{~m}^{2} / \mathrm{g}$. Salawudeen et al. [15] conducted a study on removing carotene content in vegetable oils and obtained $33.3 \%$ higher yields when using alkalineactivated clays. The development of research on pillared clay shows that pillared clay has been widely used to adsorb dyes. Ti pillared clay increased its absorptivity properties due to an increase in surface area from $65 \mathrm{~m}^{2} / \mathrm{g}$ to $216 \mathrm{~m}^{2} / \mathrm{g}$, pore volume from $1 \times 10^{-3} \mathrm{~cm}^{3} / \mathrm{g}$ to $8 \times 10^{-2}$ $\mathrm{cm}^{3} / \mathrm{g}$, and an increase in the number of Lewis acid sites [16]. Al-pillared clay (Al-PILC) from Tunisian bentonite was used to adsorb methylene blue [17]. Al-PILC with Pd metal doping was also used to decolorize azo and triarylmethane dyes [18]. According to Najafi et al. [19], Al pillared clay has a specific area of $00-300 \mathrm{~m}^{2} / \mathrm{g}$ and basal spacing $\left(d_{001}\right)$ of $1.7-2 \mathrm{~nm}$, while Ti pillared clay has a specific area of $100-350 \mathrm{~m}^{2} / \mathrm{g}$ and basal spacing $\left(d_{001}\right)$ of $1.2-1.8 \mathrm{~nm}$.

Based on some of these studies, this study prepared Al pillared clay to adsorb $\beta$-carotene in red fruit oil. $\beta$ carotene has a relatively large size with the molecular formula $\mathrm{C}_{40} \mathrm{H}_{56}$, which consists of combining eight isoprene units $\left(\mathrm{C}_{5} \mathrm{H}_{8}\right)$ [20]. The choice of Al pillar is because Al produces pillared clay with higher basal spacing. Clay minerals have a particle size of $<4 \mu \mathrm{m}$. Small clays have a larger surface area, and characters such as cation exchange capacity, catalytic properties, and plastic properties are higher than larger clays [21]. There has been no study on the pillarization of the clay fraction, even though natural clay contains clay particles of various sizes. In our opinion, it is necessary to study the character of pillared clay from different clay fractions. This work reports on the preparation and characterization of aluminum pillared clays in light and heavy fractions of clays, originating from Boyolali, Central Java, and their use to adsorb dyes in red fruit oil.

\section{Methodology}

\subsection{Materials and Tools}

Materials: Natural clay from Boyolali, Central Java, $\mathrm{HCl}$ (Merck, 37\%), distilled water, $\mathrm{AlCl}_{3} \cdot 6 \mathrm{H}_{2} \mathrm{O}$ (Merck),
$\mathrm{NaOH}$ (Merck), red fruit oil from Papua, alcohol (Merck, $99 \%)$. All reagents were in analytical grade. Equipment: glassware, 170 mesh sieve, oven (Binder), furnace (Vulcan 3-130), desiccator, analytical balance (Ohaus), magnetic stirrer, Whatman filter paper, shaker (Maxq 2000), Xray Diffractometer (Shimadzu), Gas Sorption Analyzer (Quantachrom Instruments version 11.0), UV-Vis spectrophotometer (Perkin Elmer).

\subsection{Clay preparation and fractionation}

Natural clay is washed with water, oven-dried at $105^{\circ} \mathrm{C}$ for 3 hours. Clay fractionation is carried out by making a clay suspension in water until the light fraction is at the top and the heavy fraction is at the bottom. The two fractions were separated by decantation, then each dried at $105^{\circ} \mathrm{C}$. Each clay fraction, the heavy fraction (HF), and the light fraction (LF) that had dried were crushed and sieved in 170 mesh size.

\subsection{Clay Activation}

Every 100 grams of $\mathrm{HF}$ and LF clays were reacted with $200 \mathrm{~mL}$ of $2 \mathrm{M} \mathrm{HCl}$. The mixture was stirred for 24 hours, then allowed to stand for 24 hours, then filtered. The solid was washed with distilled water to remove $\mathrm{Cl}^{-}$and ovendried at $105^{\circ} \mathrm{C}$ for 3 hours. The resulting solid was characterized by XRD (X-ray Diffraction).

\subsection{Clay pillarization with aluminum cations}

The pillar solution was made by mixing the $\mathrm{NaOH}$ solution into the $\mathrm{AlCl}_{3} .6 \mathrm{H}_{2} \mathrm{O}$ solution with a mole ratio of 1: 1 to obtain a concentration of $0.3 \mathrm{M}$ aluminum pillar solution. The mixture was continuously stirred for 24 hours using a magnetic stirrer. This pillar solution was mixed respectively into the clay suspension of an activated heavy fraction (HF) and a light fraction (LF) and stirred for 24 hours, then left to stand at room temperature for 24 hours. The results of intercalation/pillarization were filtered, then washed with water and dried in an oven at $105^{\circ} \mathrm{C}$ for 3 hours. Then the dry solid was calcined at a temperature of $450^{\circ} \mathrm{C}$ for 2 hours with a temperature ramp rate of $1^{\circ} \mathrm{C} /$ minute. From this stage, heavy fraction and light fraction $\mathrm{Al}$ pillared clay (Al-PILC) were obtained. Each aluminum pillar clay was characterized by XRD (X-ray Diffraction) to determine basal spacing and GSA (Gas Sorption Analyzer) to determine pore and surface characteristics.

\subsection{Performance test of Al-PILC on $\beta$-carotene absorption of red fruit oil}

Red fruit oil was diluted with alcohol. The ratio of AlPILC adsorbent: red fruit oil adsorbate was $5 \%(\mathrm{w} / \mathrm{v})$. The adsorption was carried out with all Al-PILC adsorbents against diluted red fruit oil with a contact time of 10 minutes. The adsorption results were filtered to obtain the filtrate. Then the filtrate was analyzed using a UV-Vis spectrophotometer at a maximum wavelength of $460 \mathrm{~nm}$. With the same procedure, red fruit oil adsorption was also carried out using the initial clay adsorbent before fractionation, activated HF, and LF clays. From this step, information on which adsorbent has the best adsorption obtained. 


\section{Results and Discussion}

\subsection{Characters of Aluminum pillared clay (Al-PILC)}

In this study, the natural clay fraction from Boyolali was separated into a heavy fraction (HF) which precipitated, and a light fraction (LF) floated. After being activated, the two clay fractions were polarized using an $\mathrm{Al}$ pillar. Characterization of both clay fractions before and after pillared using X-ray diffractometer (XRD). It aims to determine the mineral type through the typical peaks in XRD and compared with the mineral database in the JCPDS program (Joint Committee on Powder Diffraction Standards) and see the $2 \theta$ angle peak shift and associated basal spacing.

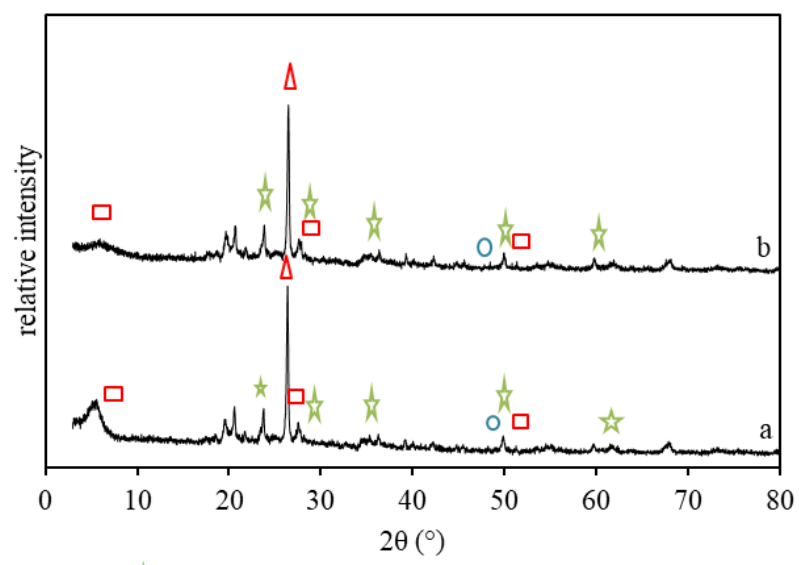

Note: $\hat{k}=$ monmorillonite, $\triangle$ = illite, $\square=$ chlorite, $\mathrm{O}=$ kaolinite

Figure 2. XRD diffraction pattern of (a) activated heavy fraction clay, (b) aluminum pillared clay of heavy fraction

Figure 2 shows that the activated heavy fraction (HF) has the highest intensity at $2 \theta=26.372^{\circ}$ and Al-PILC heavy fraction at $2 \theta=26.45^{\circ}$, almost corresponding to illite minerals $\left(\mathrm{I}=100 \%, 2 \theta=26.75^{\circ}\right)$. Apart from illite, this clay also contains montmorillonite and chlorite and a small amount of kaolinite.

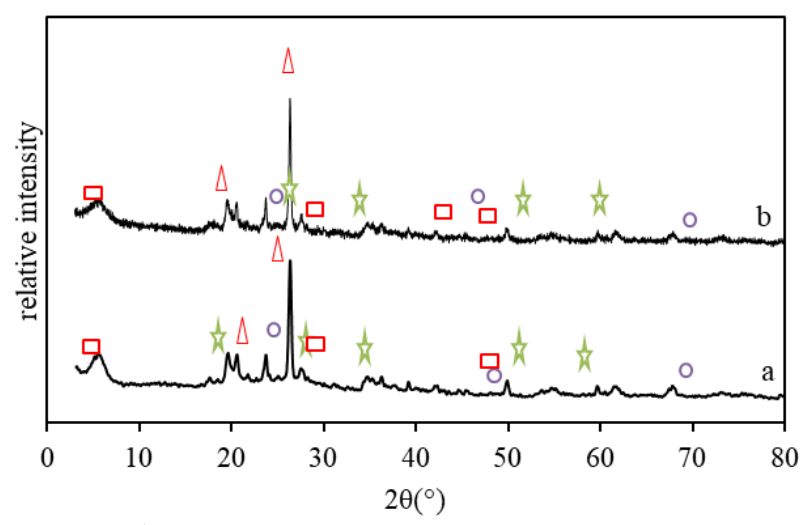

Note: $\frac{h}{h}=$ monmorillonite, $\triangle$ = illite, $\square=$ chlorite, $\mathrm{O}=$ kaolinite

Figure 3. XRD diffraction pattern of (a) activated light fraction clay, (b) aluminum pillared clay of light fraction

Figure 3 shows that the light fraction diffractogram pattern is not much different from the heavy fraction, which both show peaks in the illite mineral area, namely at $2 \theta=26.26^{\circ}$ and Al-PILC of the light fraction at $2 \theta=$ $26.29^{\circ}$. Figure 2 and Figure 3 show that the clay's composition in this study is montmorillonite, illite, chlorite, and kaolinite. The presence of $\mathrm{Al}_{2} \mathrm{O}_{3}$ was not explicitly indicated because there was no new peak after the clay was pillared with Al. This is possible because the small amount of added alumina oxide in Al-PILC does not affect the XRD diffractogram pattern. Also, the clay itself already contains alumina tetrahedra in its skeleton. There was no change in the clay diffractogram pattern before and after pillarization, indicating that the clay structure did not change much [22]. When viewed from the basal spacing, both the pillared heavy and light fraction experienced an increase in basal spacing when compared to activated clays, as presented in Table 1.

Table 1. The basal spacing of each adsorbent

\begin{tabular}{cccc}
\hline Samples & $2 \theta\left({ }^{\circ}\right)$ & $\mathrm{I}(\%)$ & $\mathrm{d}(\AA)$ \\
\hline Activated heavy fraction clay & 5.96 & 29.98 & 14.81 \\
aluminum pillared clay of heavy fraction & 5.78 & 25.77 & 15.27 \\
Activated light fraction clay & 5.44 & 42.64 & 16.22 \\
aluminum pillared clay of light fraction & 5.24 & 40.07 & 16.84 \\
\hline
\end{tabular}

Natural clays have interlayer areas. There are various kinds of cations such as $\mathrm{K}^{+}, \mathrm{Na}^{+}, \mathrm{Ca}^{2+}, \mathrm{Mg}^{2+}$, and $\mathrm{Fe}^{2+}$, which function as a load balancer for the clay layer is negative, which causes the size between the clay layers to be non-uniform. The light fraction contains montmorillonite, illite, kaolinite, and chlorite, each with different properties. According to Raharjo and Sarmili [23], the fine fraction with a size of $<0.002 \mu \mathrm{m}$ has larger plastic properties. Thus it is easier to experience swelling and is lighter. The light fraction has an illite component where $\mathrm{K}^{+}$ions dominate this type as a counterweight to the clay charge. In this case, the size of the radius of the $\mathrm{K}^{+}$ion is larger than that of the other ions, which results in a larger basal spacing.

The increase in basal spacing in the heavy fraction (HF) and the light fraction (LF) pillared was caused by a change in the balancing cation from the small cation, which was then substituted by the aluminum pillar polycation. The polycation of the Keggin $\mathrm{Al}_{13}$ ion has a large size. When the $\mathrm{Al}_{13}$ polycation enters the area between the clay layers, the distance between the layers increases. The calcination process at a temperature of $450^{\circ} \mathrm{C}$ converts the $\mathrm{Al}$ polycation into a more stable metal oxide. In this study, the light fraction of Al-PILC had a peak at $2 \theta=5,24^{\circ}$ or basal spacing $16.84 \AA$. This result is similar to Kostriati's study [22], which was Al-pillared bentonite calcined at $500^{\circ} \mathrm{C}$.

Figures 2 and 3 prove that the basal spacing values of Al-PILC for the heavy and light fraction and the activated light fraction were higher than the activated heavy fraction. Based on Bragg's law, $\mathrm{n} \lambda=2 d \sin \theta$, if there is a shift at $2 \theta$ to the right, the basal spacing value gets smaller, and if there is a shift to the left, the basal spacing value will be higher.

Data on the surface area, pore volume, and pore diameter of pillared clay are presented in Table 2 . Table 2 shows that the heavy fraction of the Al-PILC clay has a smaller surface area and pore volume. The pore volume of 
the heavy fraction of Al-PILC was $0.0516 \mathrm{cc} / \mathrm{g}$, while the light fraction was $0.995 \mathrm{cc} / \mathrm{g}$. Meanwhile, the mean pore diameter of the heavy fraction of Al-PILC was greater than that of the light fraction. This shows that the light fraction of Al-PILC has smaller pores, but a lot, or can be said to be more porous than the heavy fraction.

Table 2. Pore and surface characters of aluminum pillared clays of heavy fraction and light fraction

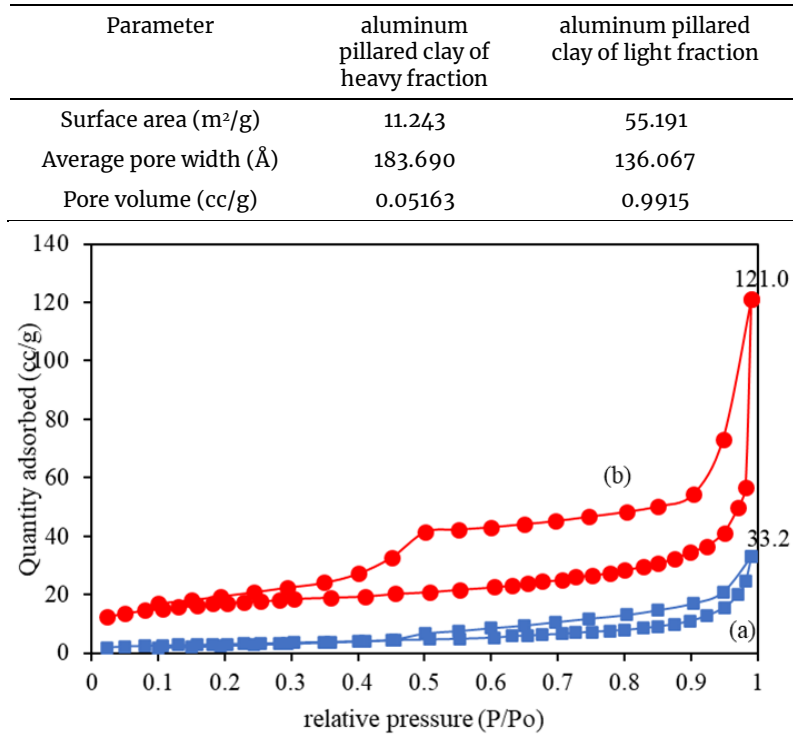

Figure 4. Adsorption isotherms of (a) aluminum pillared clay of heavy fraction and (b) light fraction

Figure 4 shows the adsorption isotherm curve of a light fraction of Al-PILC. A heavy fraction of Al-PILC is of type IV in the IUPAC classification indicating mesoporous material. Type IV isotherms are characterized by a hysterical loop caused by capillary condensation. Figure 4 shows that at $\mathrm{P} / \mathrm{P}^{\circ}=0.01$, the gas adsorbed very little so that only a little monolayer. When the pressure is increased $\mathrm{P} / \mathrm{P}^{\circ}<0.2$, the adsorbed gas begins to saturate the monolayer. When the pressure is increased to 0.6 , the gas adsorption in the multilayer begins to occur. At $\mathrm{P} / \mathrm{P}^{\circ}=$ 1, gas molecules fill the mesoporous, after which the pressure begins to decrease for gas desorption. When the pressure is lowered, there is an isothermal graph showing the hysteresis loop. The desorption isotherm shows that the amount of desorbed gas is not the same as the amount initially adsorbed due to capillary condensation. The volume of nitrogen gas adsorbed by Al-PILC LF was much greater than that of Al-PILC HF. This result is in line with carotene dyes' adsorption power in red fruit, which will be explained later.

Figure 5 shows that the pores of all the aluminum pillared clay samples obtained are mostly located in the diameter range of $30-100 \AA$, which is included in the mesoporous category. The pore size distribution was not uniform, as indicated by the presence of several peaks. This non-uniform pore size is probably caused by the $\mathrm{Al}_{2} \mathrm{O}_{3}$ pillars formed in the area between the clay layers, which are not uniform and unevenly distributed.

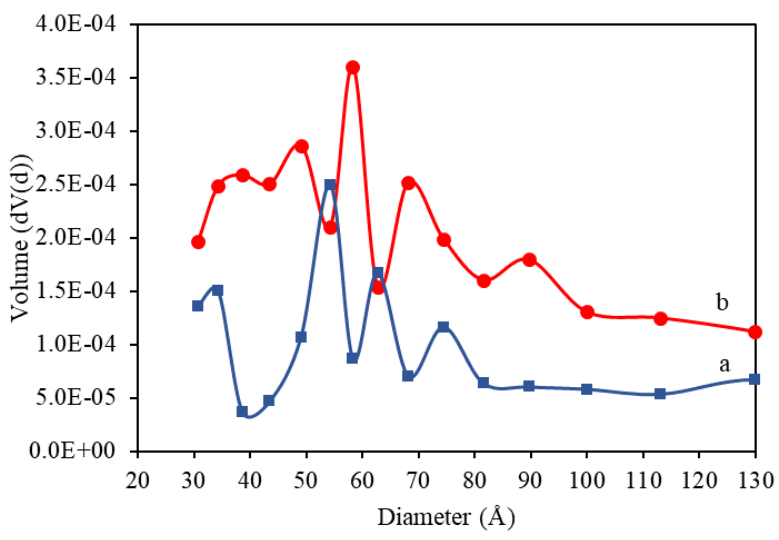

Figure 5. The pore size distribution of (a) aluminum pillared clay of heavy fraction and (b) light fraction

\subsection{Adsorption of $\beta$-carotene in red fruit oil}

In this study, red fruit oil was mixed with ethanol so that it was not too thick. The reduced color concentration in red fruit oil indicates the adsorption power of the adsorbent. The absorption results for clay, heavy fraction (HF), and a light fraction (LF) before and after activation and after pillarization with $\mathrm{Al}$ obtained are presented in Figure 6.

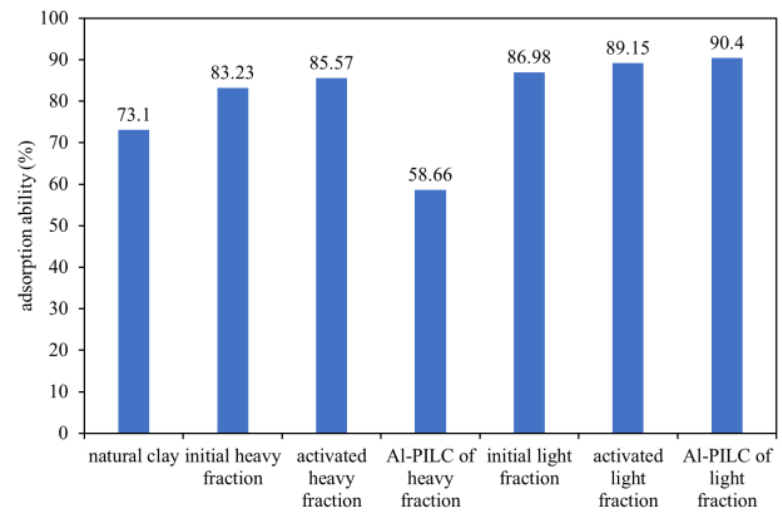

Figure 6. Adsorption ability of several absorbents

Figure 6 shows that the adsorbent's absorption ability of $\beta$-carotene increases when the clay is fractionated and activated, where the activated light fraction has an adsorption ability of $89.15 \%$. The adsorption process factors are the adsorbate concentration and surface area. The greater the adsorbate concentration, the adsorbate, and adsorbent interactions will increase. Furthermore, the larger the adsorbent's surface area, the greater the absorption ability to adsorb the adsorbate.

Figure 6 also shows the adsorption ability of Al-PILC. Al-PILC of the light fraction has an adsorption power of $90.4 \%$, where this value is higher when compared to AlPILC of the heavy fraction, which can only adsorb $58.66 \%$. This adsorption ability is in accordance with the adsorption isotherm in Figure 4, where Al-PILC of a light fraction can adsorb $121.45 \mathrm{cc} / \mathrm{g}$ of nitrogen gas, but AlPILC of the heavy fraction is only $33.22 \mathrm{cc} / \mathrm{g}$. This is also in line with the data presented in Table 2 that the Al-PILC of the light fraction has a larger surface area and pore volume than the heavy fraction so that the light fraction interacts with more $\beta$-carotene dyes. Likewise, if it is 
related to pore size, the Al-PILC of the light fraction is smaller than the heavy fraction, but its ability to absorb adsorbate is higher.

The adsorption ability of $\beta$-carotene in light fraction clay increased with the activation and pillarization treatment, but in clay, the heavy fraction decreased after the Al pillarization process. This decreased adsorption ability may be related to Al pillars' irregular arrangement in heavy fraction clay, or even agglomeration may occur, thus clogging the pores of heavy fraction clay. The pore size of pillared clay for Al-PILC-HF is $183.69 \AA$, and this is larger than the light fraction, which is only $136.067 \AA$. However, the surface area and pore volume are lower. Thus, it can be assumed that the pores in the Al_PILC-HF pillared clay are bigger but shallower because the Al pillar actually covers the inside of the pore. Physically, the color change in red fruit oil before and after adsorption can be seen in Figure 7.

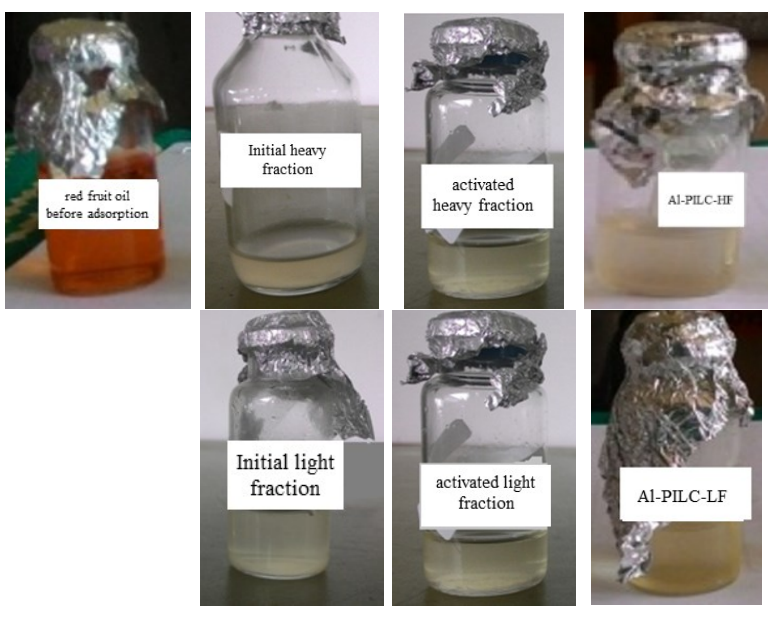

Figure 7. The color of red fruit oil before and after adsorption

The coloration of the red fruit oil occurs after the adsorption of the clay. Possible adsorption that occurs is physical adsorption due to the interaction of the adsorbent with the adsorbate through van der Waals forces. The $\beta$-carotene dye, which has a structure with the molecular formula $\mathrm{C}_{40} \mathrm{H}_{56}$, contains isoprene units. Even though the molecule is large enough, it still allows entry into the pore based on the pore diameter of Al-PILC ranging from $30-100 \AA$. Another possibility is that $\beta-$ carotene molecules are adsorbed on the clay's basal spacing with a size of $14.81-16.84 \AA$ through the ends because of their smaller size. The more $\beta$-carotene molecules that are adsorbed, the color of the red fruit oil will fade.

\section{Conclusion}

It is concluded that pillarization using aluminum can increase the basal spacing value from $14.81 \AA$ in heavy fraction clay to $15.27 \AA$ in Al-PILC of heavy fraction. Likewise, the basal spacing of $16.22 \AA$ in the light fraction was activated to $16.84 \AA$ in the Al-PILC of the light fraction. The $\beta$-carotene dye found in red fruit oil is successfully absorbed by the clay so that the red fruit oil, which has a reddish-orange color, becomes more transparent. The smallest adsorption ability occurred in Al-PILC-HF with an adsorption ability of $58.66 \%$. In comparison, the highest was obtained by Al-PILC-LF with an adsorption ability of $90.14 \%$, where this was following the structural character of the pillared clay.

\section{References}

[1] Inti Aritni Palupi, Martanto Martosupomo, Buah Merah: potensi dan manfaatnya sebagai antioksidan, Jurnal Tumbuhan Obat Indonesia, 2, 1, (2019), 42-48

[2] Zita L. Sarungallo, Purwiyatno Hariyadi, Nuri Andarwulan, Eko H. Purnomo, Mitsuhiro Wada, Analysis of $\alpha$-Cryptoxanthin, $\beta$-Cryptoxanthin, $\alpha-$ Carotene, and $\beta$-Carotene of Pandanus Conoideus Oil by High-performance Liquid Chromatography (HPLC), Procedia Food Science, 3, (2015), 231-243 https://doi.org/10.1016/j.profoo.2015.01.026

[3] Zita Letviany Sarungallo, Purwiyatno Hariyadi, Nuri Andarwulan, Eko Hari Purnomo, Characterization of chemical properties, lipid profile, total phenol and tocopherol content of oils extracted from nine clones of red fruit (Pandanus conoideus), Kasetsart Journal Natural Science, 49, 2, (2015), 237-250

[4] Desiana, Ekstraksi Pigmen Karotenoid dari Limbah Kulit Udang Windu (Penaeus monodon Fabricus) dengan Bantuan Enzim Papain, Aquatic Product Technology, IPB University, Bogor, 2000

[5] Windu Merdekawati, Ferry F. Karwur, A. B. Susanto, Karotenoid Pada Algae: Kajian Tentang Biosintesis, Distribusi Serta Fungsi Karotenoid, Bioma, 13, 1, (2017), 23-32 https://doi.org/10.21009/Bioma13(1).3

[6] Griet Knockaert, Lien Lemmens, Sandy Van Buggenhout, Marc Hendrickx, Ann Van Loey, Changes in $\beta$-carotene bioaccessibility and concentration during processing of carrot puree, Food Chemistry, 133, 1, (2012), 60-67 https://doi.org/10.1016/j.foodchem.2011.12.066

[7] Zita Letviany Sarungallo, Budi Santoso, Eduard Fransisco Tethool, Risma Uli Situngkir, Jandri Tupamahu, Kinetika perubahan mutu minyak buah merah (Pandanus conoideus) selama penyimpanan, Agritech, 38, 1, (2018), 64-70

https://doi.org/10.22146/agritech.25216

[8] Irvan, Olyvia Putri Wardhani, Nurul Aini, Iriany, Adsorpsi $\beta$-Karoten yang Terkandung dalam Minyak Kelapa Sawit (Crude Palm Oil) Menggunakan Karbon Aktif, Jurnal Teknik Kimia USU, 5, 1, (2016), 52-57 https://doi.org/10.32734/jtk.v5i1.1525

[9] Manjot Toor, Bo Jin, Sheng Dai, Vipasiri Vimonses, Activating natural bentonite as a cost-effective adsorbent for removal of Congo-red in wastewater, Journal of Industrial and Engineering Chemistry, 21, (2015), 653-661 https://doi.org/10.1016/j.jiec.2014.03.033

[10] Shella Permatasari Santoso, Artik Elisa Angkawijaya, Maria Yuliana, Vania Bundjaja, Felycia Edi Soetaredjo, Suryadi Ismadji, Alchris Woo Go, Phuong Lan Tran-Nguyen, Alfin Kurniawan, Yi-Hsu $\mathrm{Ju}$, Saponin-intercalated organoclays for adsorptive removal of $\beta$-carotene: Equilibrium, reusability, and phytotoxicity assessment, Journal of the Taiwan Institute of Chemical Engineers, 117, (2020), 198-208 https://doi.org/10.1016/j.jtice.2020.11.036

[11] Edson Luiz Foletto, Diego Silva Paz, André Gündel, Acid-activation assisted by microwave of a Brazilian bentonite and its activity in the bleaching of soybean 
oil, Applied Clay Science, 83-84, (2013), 63-67 https://doi.org/10.1016/j.clay.2013.08.017

[12] Gabriele Centi, Siglinda Perathoner, Catalysis by layered materials: A review, Microporous and Mesoporous Materials, 107, 1, (2008), 3-15 https://doi.org/10.1016/j.micromeso.2007.03.011

[13] Manisha Chauhan, Vipin K. Saini, Surendra Suthar, Enhancement in selective adsorption and removal efficiency of natural clay by intercalation of $\mathrm{Zr}$ pillars into its layered nanostructure, Journal of Cleaner Production, 258, (2020), 120686 https://doi.org/10.1016/i.jclepro.2020.120686

[14] Hani Nurhayati, Pemanfaatan Bentonit Teraktivasi Dalam Pengolahan Limbah Cair Tahu, Department of Chemistry, Universitas Sebelas Maret, Surakarta, 2010

[15] T. O. Salawudeen, A. O. Arinkoola, M. O. Jimoh, B. A. Akinwande, Clay characterization and optimisation of bleaching parameters for palm kernel oil using alkaline activated clays, Journal of Minerals and Materials Characterization and Engineering, 2, 6, (2014), 586-597

http://dx.doi.org/10.4236/jmmce.2014.26060

[16] Manisha Chauhan, Vipin K. Saini, Surindra Suthar, Ti-pillared montmorillonite clay for adsorptive removal of amoxicillin, imipramine, diclofenacsodium, and paracetamol from water, Journal of Hazardous Materials, 399, (2020), 122832 https://doi.org/10.1016/j.jhazmat.2020.122832

[17] Oumaya Issaoui, Hédi Ben Amor, Mohamed Ismail, M-Razak Jeday, Preparation of Al-pillared clay and application of methylene blue adsorption, 2017 International Conference on Green Energy Conversion Systems (GECS), 2017

https://doi.org/10.1109/GECS.2017.8066219

[18] A. H. Pizarro, C. B. Molina, J. J. Rodriguez, Decoloration of azo and triarylmethane dyes in the aqueous phase by catalytic hydrotreatment with $\mathrm{Pd}$ supported on pillared clays, RSC Advances, 6, 115, (2016), 113820-113825

https://doi.org/10.1039/C6RA24542K

[19] Hanieh Najafi, Samira Farajfaed, Sheida Zolgharnian, Seyed Heydar Mosavi Mirak, Neda Asasian-Kolur, Seyedmehdi Sharifian, A comprehensive study on modified-pillared clays as an adsorbent in wastewater treatment processes, Process Safety and Environmental Protection, 147, (2021), 8-36

https://doi.org/10.1016/j.psep.2020.09.028

[20] Nururrahmah Hammado, Wiwied Widiarnu, Analisis Kadar Beta-Karoten Kulit Buah Naga Menggunakan Spektrofotometer UV-VIS, Dinamika, 4, 1, (2015), $15-26$

[21] J. M. Huggett, Clay Minerals, in: Reference Module in Earth Systems and Environmental Sciences, Elsevier, 2015

https://doi.org/10.1016/B978-0-12-4095489.09519-1

[22] Toeti Koestiari, Karakter Bentonit Terpilar Logam Aluminium pada Variasi Suhu Kalsinasi, Molekul, 9, 2, (2014), 144-154 http://dx.doi.org/10.20884/1.jm.2014.9.2.162

[23] Purnomo Raharjo, Lili Sarmili, Keterdapatan Mineral Lempung Smektit yang Mempunyai Sifat
Plastisitas Tinggi di Perairan Cirebon, Jawa Barat, Jurnal Geologi Kelautan, 14, 1, (2017), 53-63 http://dx.doi.org/10.32693/jgk.14.1.2016.339 